\title{
Trends in the detections of a large frugivore (Hemiphaga novaeseelandiae) and fleshy-fruited seed dispersal over three decades
}

\author{
Joanna K. Carpenter $^{1 *}$, Dave Kelly ${ }^{1}$, Mick N. Clout ${ }^{2}$, Brian J. Karl ${ }^{3}$ and Jenny J. Ladley ${ }^{1}$ \\ ${ }^{1}$ Centre for Integrative Ecology, School of Biological Sciences, University of Canterbury, Private Bag 4800, \\ Christchurch 8140, New Zealand \\ ${ }^{2}$ Centre for Biodiversity and Biosecurity, University of Auckland, Private Bag 92019, Auckland 1142, New Zealand \\ ${ }^{3}$ Landcare Research, PO Box 69040, Lincoln 7640, New Zealand \\ *Author for correspondence (Email: carpenter.jk@gmail.com)
}

Published online: 2 December 2016

\begin{abstract}
The kereru (Hemiphaga novaeseelandiae) is a large fruit pigeon that in New Zealand is an important seed disperser for native plant species. However, little is known about recent changes in kereru densities and how these changes might affect seed dispersal services. We used long-term kereru counts and seedfall trap data from Pelorus in Marlborough to measure trends in bird abundance and seed dispersal. Using monthly kereru counts from 1983-1989 and 2002-2006, we found that counts significantly decreased between the two decades. Most of this decline was driven by changes in the seasonal abundance of kereru: a pronounced late-winter/spring peak in numbers in the 1980 s had almost vanished by the 2000 s. The late-winter/spring increase in kereru in the 1980s was probably driven by kereru moving into the area to feed on lowland foliage. Therefore, the reduction of late-winter/spring kereru in the 2000s could be driven by either a change in regional movement patterns or an authentic decline in the kereru population. Seedfall data for six fleshy-fruited trees (tawa Beilschmiedia tawa, miro Prumnopitys ferruginea, matai Prumnopitys taxifolia, hinau Elaeocarpus dentatus, rimu Dacrydium cupressinum, and kahikatea Dacrycarpus dacrydioides) from 1986-1990 and 2004-2010 allowed estimation of the percentage of each fruit crop handled by frugivores (an index of dispersal quantity). We found that the percentage of seeds handled by frugivores was higher in the 2000s than in the 1980s for tawa, and lower for matai. Seed handling rates were unchanged between the two decades for miro, hinau, rimu, and kahikatea. Over this time period there was no overall worsening in dispersal quantity between the two decades, probably because kereru numbers did not change significantly during the autumn fruiting season, and because other birds could be important dispersers for smaller-seeded species.
\end{abstract}

Keywords: Columbidae; dispersal failure; dispersal quantity; kereru; mutualisms; Pelorus; seasonality

\section{Introduction}

Habitat loss, illegal harvesting, and invasive species have resulted in global declines of frugivores, generating concern for seed dispersal services (Şekercioğlu et al. 2004). Largebodied avian frugivores are particularly susceptible to decline, due to their typically lower population densities, larger home ranges, and lower reproductive rates (Boyer 2010). Many trees have frugivore-dispersed seeds, so frugivores play an important role in the maintenance of plant communities. For example, over $59 \%$ of trees and $48 \%$ of all woody plants in New Zealand produce frugivore-dispersed fruits (Burrows 1994; Kelly et al. 2010).

The New Zealand pigeon, or kererū (Hemiphaga novaeseelandiae), is a large-bodied (c. $650 \mathrm{~g}$; Clout \& Tilley 1992) endemic New Zealand frugivore. Kererū historically suffered major declines due to hunting, but have been protected by law since 1921, resulting in them persisting in most districts that contain remnants of lowland forest (Clout et al. 1995). The contemporary threats they face are predation by introduced predators, poaching, and occasional episodes of mortality in late winter and early spring, possibly due to degraded habitat and subsequent poor nutrition (Clout et al. 1995). The International Union for Conservation of Nature and Miskelly et al. (2008) list them as near threatened and not threatened respectively, yet surprisingly little is known about their more recent population trends. Several kererū populations studied in the 1990s appeared to be highly susceptible to ongoing decline due to their high mortality rates and low reproductive success (Clout et al. 1995; Pierce \& Graham 1995). Despite these worrying observations, the distribution of kererū appears to be increasing, with kererū occupying $58.1 \%$ of national grid squares from 1999 to 2004 (Robertson et al. 2007), up from 46.6\% between 1969 and 1979 (Bull et al. 1985), although survey effort differed between the two time periods.

Kererū are frequently cited as a keystone species pivotal to the health of podocarp-broadleaf forests due to their widespread distribution, mobility, and diverse diet, which includes fruits from over 70 plant species (McEwen 1978; Clout \& Hay 1989), although smaller native birds also make important contributions to dispersal (Kelly et al. 2006). Kererū are the primary disperser for New Zealand's six largest-seeded native plants: tawa (Beilschmiedia tawa), taraire (Beilschmiedia tarairi), puriri (Vitex lucens), karaka (Corynocarpus laevigatus), Elingamita johnsonii and tawapou (Planchonella costata). Therefore, fluctuations in kererū numbers are expected to have important ramifications for seed dispersal services. The percentage of a fruit crop that has passed through an animal (fruit-handling) is related to dispersal quantity, which is an important indicator of the status of dispersal interactions (Wyman 2013). Surprisingly, there are only a handful of studies of dispersal quantity in New Zealand, the majority of which 
found adequate dispersal rates (Kelly et al. 2010). However, it appears that the mainland (North, South, and Stewart Islands) has slower or poorer fruit removal rates compared to island sanctuaries that retain higher bird densities (McNutt 1998; Robertson et al.2008). As reductions in dispersal services may have negative consequences for plant regeneration (Wotton \& Kelly 2011), evaluating long-term trends in both dispersal quantity and kererū abundances on the mainland is important.

We used two long-term datasets to measure changes in bird abundance and fruit handling in the Pelorus Bridge area, Marlborough. One was a dataset of monthly kererū counts from 1983-1989 and 2002-2006. The other was indices of annual seedfall data for six fleshy-fruited trees (rimu (Dacrydium cupressinum), kahikatea (Dacrycarpus dacrydioides), miro (Prumnopitys ferruginea), matai (Prumnopitys taxifolia) (all Podocarpaceae), tawa (Beilschmiedia tawa, Lauraceae), and hīnau (Elaeocarpus dentatus, Elaeocarpaceae)) from 1986-1990 and 2004-2010. Our research aimed to answer the following questions: (1) have kererū detections changed in the Pelorus area between the 1980s and 2000s, both overall and seasonally, and (2) is there a change in the percentage of fruits handled by frugivores (an index of dispersal quantity) for the six plant species between the 1980s and 2000s.

\section{Methods}

\section{Study site}

All seed trap data and some kererū data were collected from Pelorus Bridge Scenic Reserve $\left(41^{\circ} 18^{\prime} \mathrm{S}, 173^{\circ} 35^{\prime} \mathrm{E}\right)$ in Marlborough. The 1750 ha reserve is a lowland ( $\sim 50 \mathrm{~m}$ a.s.1.) remnant of old-growth, tawa-podocarp forest, contiguous with Mt Richmond Forest Park to the southwest. It contains stands of matai and kahikatea, with miro, totara (Podocarpus totara), rimu, and hīnau, mixed with dense areas of tawa, kāmahi (Weinmannia racemosa), and beech (Fuscospora spp.). No five-minute bird counts were conducted at the site, but other important avian frugivores such as tūī (Prosthemadera novaeseelandiae), bellbirds (Anthornis melanura), and silvereyes (Zosterops lateralis) are present in the general area (Robertson et al. 2007). Additional kererū data were collected from sites in Rai Valley $\left(41^{\circ} 13^{\prime} \mathrm{S}, 173^{\circ} 34^{\prime} \mathrm{E}\right)$, Marlborough, immediately north of Pelorus Bridge. Rai Valley is a lowland river valley ( $\sim 40 \mathrm{~m}$ a.s.1.) that predominantly consists of pastureland on the river flats, scrubby hillsides, and mature podocarp-broadleaf forest at higher altitudes. Some podocarpbroadleaf forest fragments remain within the cleared land, and there are also several Pinus plantations.

\section{Kererū counts}

We used a 12-year dataset of monthly kererū counts conducted by one observer (BJK) at Rai Valley from July 1983 to December 1989 and from January 2002 to June 2006. Counts comprised walking and driving transects. These were done in the morning (0930-1200 hrs) and repeated in the reverse direction in the afternoon(1300-1530 hrs). Each time a transect was walked or driven it was considered a count. A bird that was seen or heard (typically flying) was counted. Any bird that was considered to have already been counted was not included again in the count tally. Thus the transect counts were of individual birds and not the number of encounters of kererū.

Walking counts were made while walking slowly along forest tracks or along a road (Fig. 1). Habitats sampled in these areas include: (A) Pelorus Bridge Scenic Reserve, a bush track walk through mature beech-podocarp-broadleaf forest, dominated by rimu, kahikatea, matai, miro, tawa, kāmahi and Coprosma spp.; (B) Carluke Reserve, a small $(\sim 15 \mathrm{ha})$ remnant kahikatea and matai-dominant forest patch with a riparian strip of exotic deciduous willow (Salix spp.), poplar (Populus spp.) and native kōwhai (Sophora spp.) trees alongside the Rai river; and (C) Bulford, a $\sim 1.0 \mathrm{~km}$ road walk surveying open pasture land and a riparian strip comprising mostly willow, kōwhai, and beech trees.

Driving counts were made from a vehicle moving at about $70 \mathrm{~km}$ per hour. This habitat was typically open farmland with a riparian strip of vegetation comprising mainly exotic deciduous species (willows and poplars), kōwhai, and beech alongside the Rai River (Fig. 1; transects D (Rai Saddle) and E (Awakahakaha)). Exotic plantation forestry (Pinus spp.) occurred on both sides of the road along almost half of road transect A, and introduced broom (Cytisus scoparius) and the occasional wilding cherry (Prunus avium) grew along the roadside berm. We did not conduct habitat assessments at any of the sites, but there was no major change in habitat between the 1980s and 2000s. The observer also recorded casual observations of the food sources on which kererū were feeding and how conspicuous the birds were.

\section{Seedfall counts}

To analyse changes in the percentage of fruit handled by frugivores at Pelorus Bridge Scenic Reserve, seedfall offleshyfruited species was measured using seed traps. We sampled

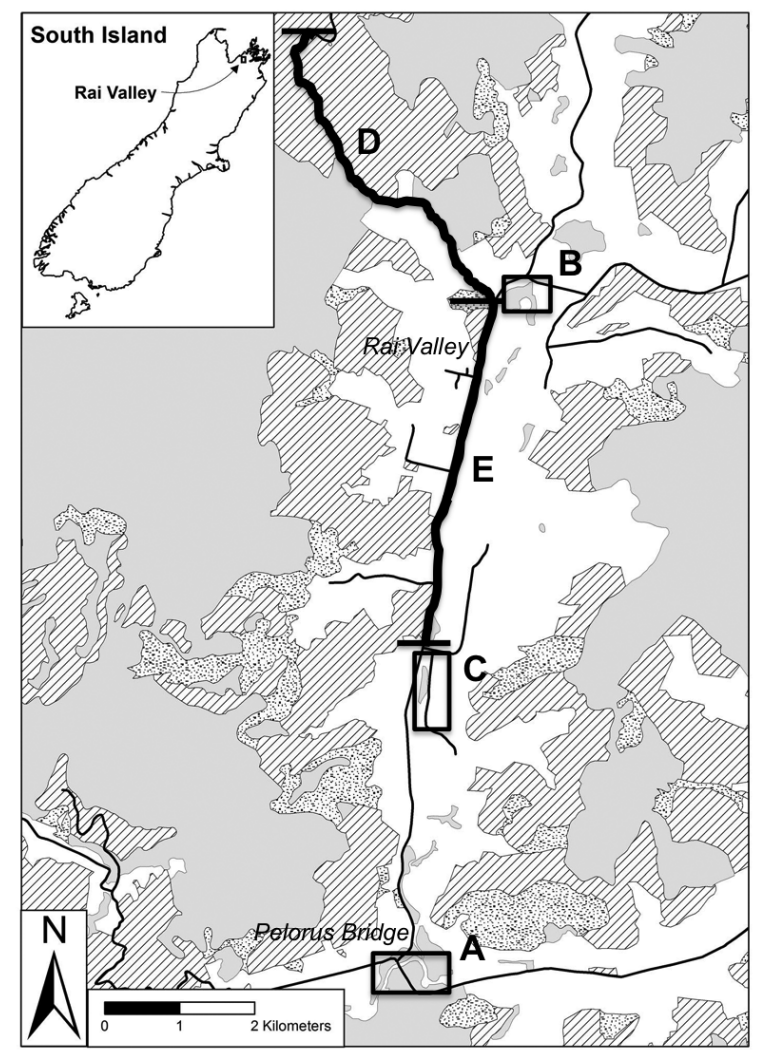

Figure 1. Map of Rai Valley showing walking transect sites Pelorus Bridge (A), Carluke Reserve (B), Bulford (C), and road transects Rai Saddle (D) and Awakahakaha (E). Grey areas denote native forest, dotted areas denote native scrub, white areas denote cleared land, and thatched areas denote exotic forest. 
seedfall of the six most common fleshy-fruited species at the site: rimu, kahikatea, matai, miro, tawa, and hīnau. Strictly speaking, the Podocarpaceae produce reduced female cones with fleshy coverings or bases, but henceforth, for simplicity, we refer to all as fruits. All species produce single-seeded fruits so fruit number and seed number are interchangeable. Seedfall was monitored from 1986-1990 and 2004-2010. In 1986 , seedfall traps were established beneath the canopies of reproductive adult trees (females for the podocarp species) of each of the six study species. Each species was allocated ten traps with the exception of rimu, which was allocated only five traps due to a shortage of reproductive female trees at the study site. Seedfall traps used from 1986 until 2009 were $0.10 \mathrm{~m}^{2}$ cones suspended $1 \mathrm{~m}$ above ground; from 2010 these traps were replaced in the same locations by $0.28 \mathrm{~m}^{2}$ cone traps suspended $1.2 \mathrm{~m}$ above the ground. Seed traps were opened on 1 January each year, then emptied on the first day of every month or second month over the fruiting season (January to October). The six species have overlapping fruiting phenologies at the site, with $78-95 \%$ of the annual seedfall being collected between January and May (Jana Prado 2012). Samples were air-dried and fruits belonging to the study species were identified. These fruits were classed as either: handled by frugivores (clean seeds, with no fleshy pulp attached), damaged (with insect exit holes or mammal bite marks), or whole fruits found under parent trees. Very occasionally clean seeds also showed signs of predation; these fruits were not given their own classification due to how infrequently they occurred. Fruits handled by frugivores were easy to distinguish as they have a distinctive clean appearance with no flesh remaining on the seed, whereas fruits that have rotted or been preyed upon have some flesh remaining on the seed or incisor marks. From 2004-2010 non-viable fruits (green, unripe fruits) and whole fruits falling away from parent trees were also recorded, but non-viable fruits were excluded from our analysis.

\section{Statistical analysis}

As there were only 7 years of overlapping kererū and seed trap data, we analysed trends in kererū counts and fruit handling rates separately. We examined changes in kererū abundance between the 1980s and 2000s by using the lme4 package (Bates et al. 2015) in R (R Core Team 2015) to generate a Poisson-distributed generalised linear mixed regression model (GLMM) with decade and month as fixed effects, and site as a random effect. Site referred to the five sites where counts were conducted (i.e. Rai Valley, Awakahakaha, Carlukes Reserve, Bulford, or Pelorus Bridge). Preliminary graphs depicted an August peak in kererū numbers, so months were converted to radians (with August $=0$ ) and fitted with a cosine curve in the GLMM (i.e. cos[radians]) to test for seasonal changes in abundance (Stolwijk et al. 1999), using an interaction term between decade and cos[radians]. We added an observation level random effect to control for overdispersion (Browne et al. 2005). We also ran a generalised linear model (GLM) with a decade and cos[radians] interaction term and quasibinomial poisson family for the Pelorus Bridge kererū counts only, in order to assess changes in kererū detections at the same site as the seedfall counts. Lastly, we ran a GLM with decade as a predictor on the Pelorus Bridge kererū counts from January to June only, to determine whether kererū counts over the peak fruiting season changed between the two decades.

To analyse changes in dispersal quantity, we used the percentage of fruits that had been handled by birds out of the total fruit crop (i.e. handled by frugivores, whole, and damaged) for each species, summed across all traps (including those beneath other species) and all months to give an annual total. Whole fruit totals were underestimated from 1986-1990 due to whole fruits falling away from parent trees not being recorded, so we corrected these totals using proportions calculated from the 2004-2010 seed fall data. The proportions of whole fruits which were found in traps away from parent trees were 0.25 for hīnau, 0.05 for kahikatea, 0.22 for matai, 0.08 for miro, 0.96 for rimu, and 0.47 for tawa. Annual totals were classified as being either from the 1980s or 2000s. We used the lme4 package in $\mathrm{R}$ to generate a quasibinomial generalized linear model with the percentage of fruit handled by frugivores as a response, and decade as a predictor. We also calculated the percentage of fruits that had been handled by birds using data from seedfall traps under parent trees only, in order to allow comparisons with other sites that use the same metric.

\section{Results}

\section{Kererū counts over time}

Average numbers of kererū counted across all sites were 0.95 \pm 1.7 (mean $\pm 95 \% \mathrm{CI}$ ) birds per count for the 1980 s and $0.25 \pm$ 0.60 for the 2000 s (Fig. 2). We found a significant interaction in our GLMM between decade and $\cos$ [months] $(\mathrm{Z}=-4.962$, $\mathrm{P}=<0.0001$ ), meaning that kererū counts significantly declined between the 1980s and 2000s due to a change in seasonal
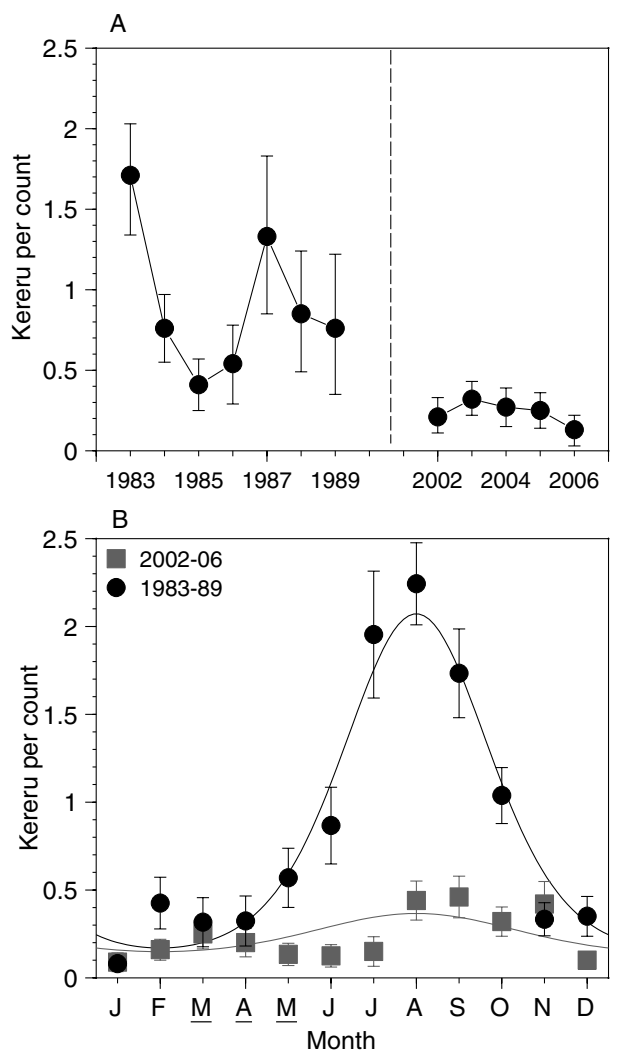

Figure 2. Changes in kererū counts in the Pelorus area 1983-2006. (a) Annual mean kererū per count $( \pm 95 \% \mathrm{CI})$ on fixed transects in and around Pelorus Bridge, averaged across all months and sites. (b) Monthly counts (mean $\pm 95 \%$ CI, with line showing GLMM fitted values) from 1983-89 and 2002-06. The austral autumn is March-May (underlined on X axis) and winter June-August. Kererū significantly declined between the two decades, mainly due to a decrease in July-September detections. 
abundance (Fig. 2a). Considering only the Pelorus Bridge data, the GLM found that decade $(\mathrm{T}=3.422, \mathrm{P}=0.0007)$ and $\cos [$ months $](\mathrm{T}=2.669, \mathrm{P}=0.008)$ were significant terms, but the decade:cos[months] interaction term was not $(\mathrm{T}=$ $-1.640, \mathrm{P}=0.102)$. Therefore, kererū declined between the two decades within Pelorus Bridge, but any changes in the seasonal pattern of abundance were not large enough to be significant. When considering only the January to June counts at Pelorus Bridge, the GLM showed changes in abundance at that time of year between the 1980s and 2000s were not significant $(\mathrm{T}=-1.523, \mathrm{P}=0.13)$.

Casual observations of kererū diet and conspicuousness across both decades suggested that kererū detectability changed seasonally. In September, kererū switched from feeding on native foliage to feeding on the developing leaf buds of deciduous trees, particularly willow. Kererū were highly visible in the willows at this stage, but over the next two months as the willow leaves expanded, kererū became less visible within them, therefore decreasing detectability.

\section{Seed dispersal over time}

Annual average fruit handling rates across all seedfall traps were high for kahikatea, rimu, and miro, but lower for tawa, matai, and especially hīnau (Table 1). Data from seedfall traps under parent trees only showed broadly similar results (Table 1). Hīnau, rimu, and kahikatea fruit handling rates did

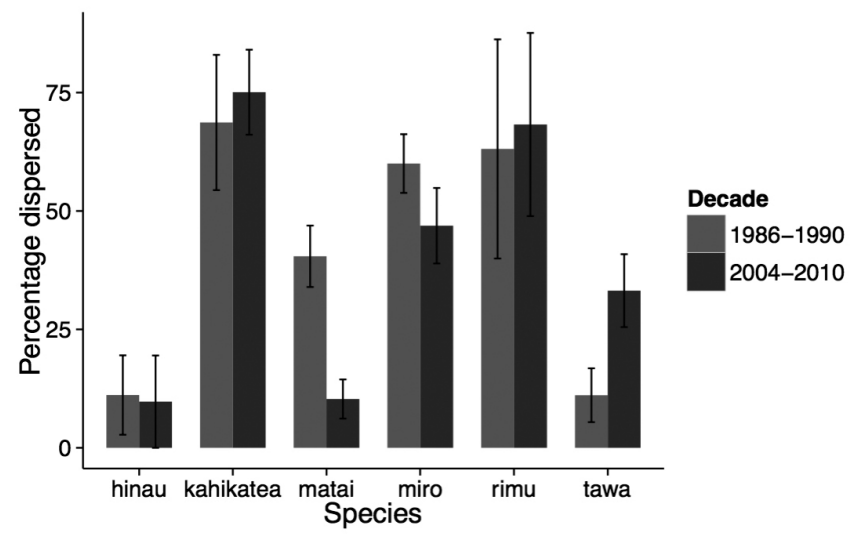

Figure 3. Percentage of fruits handled by frugivores (mean \pm SEM) per decade at Pelorus Bridge Scenic Reserve for the six study species (hīnau Elaeocarpus dentatus, kahikatea Dacrycarpus dacrydioides, matai Prumnopitys taxifolia, miro Prumnopitys ferruginea, rimu Dacrydium cupressinum, and tawa Beilshmiedia tawa). not change significantly between the two decades (Fig. 3). Fruit handling rates of tawa increased significantly between the two decades $(\mathrm{T}=3.134, \mathrm{P}=0.0139)$, while for matai rates decreased $(\mathrm{T}=-2.758, \mathrm{P}=0.0247)$.

\section{Discussion}

\section{Kererū}

Kererū counts changed seasonally in both decades, with increased counts occurring in winter and early spring. However, winter kererū counts in the 2000 s were much lower than winter kererū counts in the 1980 s, resulting in a significant decline in overall kererū detections between the two decades. Kererū diet changes throughout the year, switching from primarily fruits from February to May to mainly foliage from June to January in the upper South Island (Clout et al. 1986). Accordingly, kererū move and choose their home ranges according to food source availability (Schotbourg 2005), so it seems likely that the high winter and early spring detections in the 1980s were driven by kererū moving into open river flats to feed on foliage. In addition, Clout et al. (1991) found that Pelorus Bridge Reserve harboured a resident population of kererū that remained there year round, and a transient spring population that seasonally moved distances of up to $20 \mathrm{~km}$. The seasonal increase in detections we recorded in winter and early spring may have been due to non-resident kererū coming into the area, perhaps dispersing from native forests of Mount Richmond Forest Park in order to feed on spring foliage of willows and elms (Ulmus spp.) in the river valleys. Similarly, kererū counts at Lake Rotoroa (Nelson Lakes National Park) increased from June to September, when their diet switched from fruit to kowhai foliage on the lakeside (Clout et al. 1986). Kererū on Banks Peninsula have also been recorded occupying a circuit of seasonal home ranges (Schotbourg 2005). These findings show that kererū need to have access to either landscapes containing fragments of different habitat types or large heterogeneous forest blocks, in order to meet their seasonally changing nutritional requirements (Emeny et al. 2009).

Our observational data also suggest that kererū may have become more conspicuous in early spring due to feeding on leaf buds in willow trees with little foliage, increasing the detection rate. However, our count data show high kererū detections in the 1980s as early as July, which is too early to be explained by increased detectability while feeding on willow.

Therefore, it is unclear whether lower detections of kererū in late winter of the 2000s are due to changes in bird abundance or in bird habitat choice. Unfortunately, habitat assessments

Table 1. Fruit handling rates for the six study species (for species names see Fig. 3) with total number of fruits trapped in 1986-1990 and 2004-2010. Average percentage of fruits handled by birds is from annual totals, both from all seedfall traps at the site (overall), and from seedfall traps under conspecific trees only.

\begin{tabular}{|c|c|c|c|}
\hline Species & $\begin{array}{l}\text { Average } \% \text { of fruits } \\
\text { handled by frugivores } \\
\text { (overall) }\end{array}$ & $\begin{array}{c}\text { Average \% of fruits } \\
\text { handled by frugivores } \\
\text { (under conspecific trees only) }\end{array}$ & $\begin{array}{c}\text { Total number of fruits } \\
\text { trapped }\end{array}$ \\
\hline Miro & 52 & 39 & 876 \\
\hline Matai & 23 & 20 & 4237 \\
\hline Hīnau & 10 & 2 & 408 \\
\hline Rimu & 66 & 32 & 1069 \\
\hline
\end{tabular}


were not conducted at the site, so we do not know how resource availability and kererū detectability may have changed between the two decades. Although resources at the Pelorus Bridge site should not have changed, it is possible that trees were removed at the other sites, potentially depleting habitat quality-although we noticed no major changes to the habitat at any of the sites between the two decades. Likewise, habitat changes (such as increased food availability) may have occurred at sites that were not measured by our study, resulting in kererū moving to these unmeasured sites to feed in winter and early spring. Conversely, the data may document a genuine decline in kererū abundances. Given that Clout etal. (1995) found that the Pelorus Bridge kererū population was vulnerable to decline due to high rates of mammalian predation and low breeding success, that result would be unsurprising. Mammalian predator control was commenced at Pelorus Bridge Scenic Reserve in 2010, which may have possibly improved kererū numbers after we stopped counting them. Studies of long-term trends in other kererū populations would be valuable, in order to assess how prevalent are declines.

Our study also highlights the difficulty of monitoring kererū, due to their crypsis, seasonally mobile behaviour, and highly variable detectability. While five-minute bird counts have been the most commonly used method for monitoring diurnal birds in New Zealand since the 1970s, kererū are typically quiet and sedentary, so numbers detected per five-minute count are generally low. As a result, such counts lack the sensitivity to detect $20-30 \%$ changes in kererū abundances in very small forest patches (Mander et al. 1998). Distance sampling appears to be a better method, as it allows calculation of the effective sampling area in different habitats, and can theoretically control for differences in detectability with increasing distance from the observer (Mander et al. 1998). However, distance sampling assumes detectability directly overhead is $100 \%$ so is still affected by the general crypsis of kererū. Census counts from vantage points give a minimum estimate of the actual number of kererū using the observed area for small forest fragments, but are labour intensive and would not be as effective where the terrain is flat or where there are more than 20 birds present (Mander et al. 1998). The high degree of seasonal mobility recorded within the Rai Valley population suggests that monitoring at several times throughout the year would be optimal.

\section{Fruit-handling and dispersal}

Despite an overall reduction in kererū detections, fruit-handling rates at Pelorus did not worsen overall between the 1980s and 2000s. While fruit handling rates do not explicitly measure quantitative seed dispersal (as successful seed dispersal typically requires the movement of fruits away from beneath parent tree canopies), they are monotonically related to the percentage of seeds that are moved away from beneath the parent canopy and therefore they can function as an index of dispersal quantity (Wyman 2013). Additionally, some of the frugivore-handled fruits recorded in this study were found in traps away from parent trees and therefore were successfully dispersed. Seed dispersal at Pelorus probably did not worsen between the two decades due to the fact that $85 \%$ of the seed crop from the six fleshy-fruited trees falls between January and May, during which time period kererū at Pelorus Bridge were at similar densities over the two decades. Additionally, other bird species are likely to have been important seed dispersers for smaller-seeded tree species such as kahikatea (O'Donnell \& Dilks 1994). Bellbirds, tūī, and silvereyes are thought to be present in the reserve (Robertson et al. 2007) and are capable of making significant contributions to seed dispersal (Kelly et al. 2006). It is important to also note that while brushtail possums (Trichosurus vulpecula) are typically thought of as seed predators, they have also been recorded dispersing fruit, and therefore may be facilitating seed dispersal at Pelorus at least for smaller-seeded species (Williams et al. 2000). Tawa, miro, and hīnau are the three species that are probably now dispersed predominantly by kererū, but none of these species' dispersal declined between the two decades.

There is no objective definition of what constitutes 'good' or 'poor' dispersal quantity, so it is difficult to say whether or not the levels of dispersal quantity at Pelorus Bridge were adequate (Kelly et al. 2010). Although there are few published data, dispersal quantity at Pelorus Bridge was generally lower than at other sites in New Zealand. Over nine seasons at Blue Duck Scientific Reserve, near Kaikoura, an average of 50\% of tawa seeds underneath parent trees had been handled by frugivores (Kelly et al. 2010), compared to an average of 7\% at Pelorus. Unpublished seedfall data (JK Carpenter, unpubl. data) from Blue Duck, Waipapa, Otamatuna, Trounson and Paengaroa over 3 to 4 years found average dispersal quantities under parent trees of $67 \%$ for kahikatea, $65 \%$ for matai, $51 \%$ for miro, $62 \%$ for rimu, and $28 \%$ for hinnau. Therefore, with the exception of kahikatea, Pelorus Bridge has lower average dispersal quantities than these sites, although the averages from the other sites may be skewed by the small number of seasons over which seedfall was collected.

When the trap data from non-parent trees are included, the species we have measured at Pelorus Bridge probably have adequate dispersal, with the exception of hinau and perhaps matai. Hīnau fruits have a conspicuous metallic sheen and are dropped at maturity, prompting Lord et al. (2002) and Thorsen et al. (2011) to speculate that they may have evolved to be dispersed by flightless birds. The only extant species that have been recorded consuming hīnau are kererū, weka (Gallirallus australis), kōkako (Callaeus cinerea), and brown kiwi(Apteryx mantelli)(Kelly et al.2010), of which the latter two are severely range restricted. Low dispersal quantities for matai are more puzzling. O'Connor (2012) recorded dispersal quantities of between 19 and 55\% under matai parent trees in fragmented forest on Banks Peninsula, prompting her to speculate that matai might be an important resource for frugivorous birds in that highly modified habitat. Pelorus Bridge contains several other fleshy-fruited species, so matai may not be such an important food source and hence suffer from lower dispersal quantity at the site.

In conclusion, the results presented here illustrate the value of long-term studies to reveal potential changes in ecological services such as seed dispersal. They also highlight the importance of considering seasonality when monitoring trends in frugivore abundances and seed dispersal.

\section{Acknowledgements}

Thanks to Elena Moltchanova and Adrian Monks for statistical advice, Jim Watts for assistance with mapping, Jocelyn Tilley for help with seedfall analysis, and to the Public Good Science Fund (Contracts CO9X0004, CO9X0503) for funding counts in the 2000s. Colin O'Donnell, Sanjay Thakur, Fiona Thompson, Debra Wotton, George Perry, and an anonymous reviewer provided helpful comments on an earlier draft of this manuscript. Joanna Carpenter was supported by a University of Canterbury Roper Scholarship in Science. 


\section{References}

Bates D, Maechler M, Bolker B, Walker S 2015. Fitting linear mixed-effects models using lme4. Journal of Statistical Software 67: 1-48.

Boyer AG 2010. Consistent ecological selectivity through time in Pacific island avian extinctions. Conservation Biology 24: 511-519.

Browne WJ, Subramanian SV, Jones K, Goldstein H 2005. Variance partitioning in multilevel logistic models that exhibit overdispersion. Journal of the Royal Statistical Society: Series A (Statistics in Society) 168: 599-613.

Bull PC, Gaze PD, Robertson CJR 1985. The atlas of bird distribution in New Zealand. Wellington, New Zealand, The Ornithological Society of New Zealand.

Burrows CJ 1994. Fruit, seeds, birds and the forests of Banks Peninsula. New Zealand Natural Sciences 21: 87-87.

Clout MN, Hay JR 1989. The importance of birds as browsers, pollinators and seed dispersers in New Zealand forests. New Zealand Journal of Ecology 12 (Supplement): 27-33.

Clout MN, Tilley JAV 1992. Germination of Miro Prumnopitys ferruginea seeds after consumption by New Zealand pigeons Hemiphaga novaeseelandiae. NZ Journal of Botany 30: 25-28.

Clout MN, Gaze PD, Hay JR, Karl BJ 1986. Habitat use and spring movements of New Zealand pigeons at Lake Rotoroa, Nelson Lakes National Park. Notornis 33:37-44.

Clout MN, Karl BJ, Gaze PD 1991. Seasonal movements of New Zealand pigeons from a lowland forest reserve. Notornis 38: 37-47.

Clout MN, Karl BJ, Pierce RJ, Robertson HA 1995. Breeding and survival of New Zealand Pigeons (Hemiphaga novaeseelandiae). Ibis 137: 264-271.

Emeny MT, Powlesland RG, Henderson IM, Fordham RA2009. Feeding ecology of kererū (Hemiphaga novaeseelandiae) in podocarp-hardwood forest, Whirinaki Forest Park, New Zealand. New Zealand Journal of Ecology 33: 114-124.

Jana Prado RC 2012.Animal seed dispersal and its consequences for plant recruitment. Unpublished PhD Thesis, University of Canterbury, Christchurch, New Zealand. 154 p.

Kelly D, RobertsonAW, Ladley JJ,Anderson SH, McKenzie RJ 2006. The relative (un)importance of introduced animals as pollinators and dispersers of native plants. In: Allen RB, Lee WG eds. Biological Invasions in New Zealand. Berlin, Springer. Pp. 227-245.

Kelly D, Ladley JJ, Robertson AW, Anderson SH, Wotton DM, Wiser SK 2010. Mutualisms with the wreckage of an avifauna: the status of bird pollination and fruit-dispersal in New Zealand. New Zealand Journal of Ecology 34: 66-85.

Lord JM, Markey A, Marshall J 2002. Have frugivores influenced the evolution of fruit traits in New Zealand? In: Levey D, Silva WR, Galetti M eds. Seed dispersal and frugivory: ecology, evolution and conservation. Wallingford, Oxon, UK, CABI Publishing. Pp. 55-68.

Mander CJ, Hay JR, Powlesland R 1998. Monitoring and management of kereru (Hemiphaga novaeseelandiae). Wellington, New Zealand, Department of Conservation. $44 \mathrm{p}$.

Editorial board member: Fiona Thomson

Received 9 November 2015; accepted 15 October 2016
McEwen WM 1978. The food of the New Zealand pigeon (Hemiphaga novaeseelandiae novaeseelandiae). New Zealand Journal of Ecology 1: 99-108.

McNutt KL 1998. Impacts of reduced bird densities on pollination and dispersal mutualisms in New Zealand forests. Unpublished MSc thesis, Massey University, Palmerston North, New Zealand. 163 p.

Miskelly CM, Dowding JE, Elliott GP, Hitchmough RA, Powlesland RG, Robertson HA, Sagar PM, Scofield RP, Taylor GA 2008. Conservation status of New Zealand birds, 2008. Notornis 55: 117-135.

O’Connor SJ 2012. Quantifying seed dispersal of matai (Prumnopitys taxifolia). Unpublished PhD thesis, University of Canterbury, Christchurch, New Zealand. $135 \mathrm{p}$.

O’Donnell CFJ, Dilks PJ 1994. Foods and foraging of forest birds in temperate rainforest, South Westland, New Zealand. New Zealand Journal of Ecology 18: 87-107.

Pierce RJ, Graham PJ 1995. Ecology and breeding biology of kukupa (Hemiphaga novaeseelandiae) in Northland. Science \& Research Series No. 91. Wellington, New Zealand, Department of Conservation. $23 \mathrm{p}$.

Robertson CJR, Hyvönen P, Fraser MJ, Pickard CR 2007. Atlas of bird distribution in New Zealand 1999-2004. Wellington, Ornithological Society of New Zealand. 533 p.

Robertson AW, Ladley JJ, Kelly D, McNutt KL, Peterson PG, Merrett MF, Karl BJ 2008. Assessing pollination and fruit dispersal in Fuchsia excorticata (Onagraceae). New Zealand Journal of Botany 46: 299-314.

R Core Team 2015. R: a language and environment for statistical computing. Version 3.3.0. R Foundation for Statistical Computing, Vienna, Austria. www.R-project.org

Schotborgh HM 2005. An analysis of home ranges, movements, foods, and breeding of kereru (Hemiphaga novaeseelandiae) in a rural-urban landscape on Banks Peninsula, New Zealand. Unpublished PhD Thesis, Lincoln University, Christchurch, New Zealand. 103 p.

Şekercioğlu CH, Daily GC, Ehrlich PR 2004. Ecosystem consequences of bird declines. Proceedings of the National Academy of Sciences 101: 18042-18047.

Stolwijk AM, Straatman H, Zielhuis GA 1999. Studying seasonality by using sine and cosine functions in regression analysis. Journal of Epidemiology and Community Health 53: 235-238.

Thorsen MJ, Seddon PJ, Dickinson KJM 2011. Faunal influences on New Zealand seed dispersal characteristics. Evolutionary Ecology 25: 1397-1426.

Williams PA, Karl BJ, Bannister P, Lee WG 2000. Small mammals as potential seed dispersers in New Zealand. Austral Ecology 25: 523-532.

Wotton DM, Kelly D 2011. Frugivore loss limits recruitment of large-seeded trees. Proceedings of the Royal Society B: Biological Sciences 278: 3345-3354.

Wyman TE 2013. Consequences of reduced bird densities for seed dispersal. Unpublished PhD Thesis, University of Canterbury, Christchurch, New Zealand. 144 p. 